\title{
Pemodelan Data Penjualan Mobil Menggunakan Model Autoregressive Moving Average Berdasarkan Metode Bayesian
}

\author{
Vincentia Pawestri ${ }^{1,{ }^{*}}$, Adi Setiawan ${ }^{1}$, Lilik Linawati ${ }^{1}$ \\ ${ }^{1}$ Program Studi Matematika, Fakultas Sains dan Matematika, Universitas Kristen Satya Wacana, Salatiga, \\ Jawa Tengah 50711 \\ *email korespondensi: vinpwstr@gmail.com
}

\begin{abstract}
ABSTRAK
Penelitian ini bertujuan untuk memodelkan data penjualan mobil menggunakan salah satu model analisis runtun waktu yaitu Autoregressive Moving Average (ARMA) berdasarkan metode Bayesian. Analisis runtun waktu dipilih karena data yang digunakan berkaitan dengan waktu. Penelitian ini menggunakan metode Bayesian dikarenakan metode tersebut masih jarang digunakan dalam penelitian-penelitian sebelumnya. Analisis empiris didasarkan pada data riil yang merupakan data penjualan mobil dari bulan Januari 2013 sampai dengan Mei 2018. Berdasarkan hasil analisis menggunakan model runtun waktu, diperoleh model Autoregressive 1 (AR 1) Musiman dengan intercept yang merupakan bagian dari model ARMA. Pemodelan data dilakukan untuk mengetahui apakah data dapat diestimasi dengan metode Bayesian. Selanjutnya hasil estimasi menggunakan metode Bayesian dibandingkan dengan hasil estimasi menggunakan metode Least Square. Hasil analisis menunjukkan bahwa hasil perhitungan menggunakan metode Bayesian mendekati hasil perhitungan menggunakan metode Least Square. Hal ini menunjukkan bahwa metode Bayesian dapat digunakan untuk mengestimasi parameter model data penjualan mobil dengan model $y_{t}=30.9238+$ $0.4439 y_{t-12}+\varepsilon_{t}$.
\end{abstract}

Kata-kata kunci: AR 1; ARMA; Bayesian; pemodelan; runtun waktu

\section{PENDAHULUAN}

Di era globalisasi sekarang ini, persaingan dalam dunia bisnis semakin meningkat terutama dalam sektor industri. Industri otomotif merupakan salah satu industri yang perkembangannya sangat pesat di dunia termasuk di Indonesia. Salah satu kegiatan yang menjadikan industri otomotif dapat berkembang pesat adalah penjualan mobil. Hal tersebut tentu membuat manajer pemasaran harus mempunyai strategi yang tepat dalam memasarkan suatu produk. Strategi pemasaran yang dipilih hendaknya dapat membawa perusahaan untuk memiliki peluang yang baik di masa depan. PT. XXX (nama perusahaan dirahasiakan) merupakan salah satu dealer mobil di Salatiga yang memiliki data penjualan mobill yang fluktuatif. Oleh karena itu, perlu adanya suatu model yang dapat mempresentasikan data penjualan dalam pernyataan matematika sehingga mudah untuk dipelajari dan dilakukan perhitungan.

Adapun beberapa penelitian yang telah ada sebelumnya yang berkaitan dengan penelitian ini yaitu, penelitian yang dilakukan oleh Suparman and Doisy (2014) yang membahas tentang estimasi parameter model ARMA dengan metode Bayesian pada biaya pelayanan penumpang di Bandara Internasional Adi Sutjipto. Hasil penelitian menunjukkan bahwa dengan metode tersebut dapat diperoleh order $p$ dan $q$ serta estimasi koefisien dari $\phi, \theta, \sigma^{2}$. Selain itu, penelitian yang dilakukan oleh Entin Hidayah dkk. (2011) yang mempelajari hubungan antara sruktur model hujan terhadap pola kejadian hujan dan tinggi hujan. Estimasi model dilakukan dengan menggunakan metode Bayesian. Hasil studi menyatakan bahwa model AR 1 musiman dengan dummy merupakan model yang tepat untuk memodelkan disagregasi hujan.

Pada kasus ini, data diolah menggunakan analisis data runtun waktu ARMA (Autoregressive Moving Average) untuk mendapatkan model data penjualan mobil. Selanjutnya, untuk mengestimasi parameter digunakan metode Bayesian. Analisis runtun waktu dipilih karena data yang digunakan terkait dengan waktu dan metode Bayesian dipilih karena masih jarang digunakan dalam penelitian, sebagai pembanding digunakan metode Least Square. Oleh karena itu dilakukan penelitian untuk memperoleh model data penjualan mobil menggunakan model Autoregressive Moving Average berdasarkan metode Bayesian menggunakan paket program $\mathrm{R}$. 


\section{DASAR TEORI}

Runtun waktu (time series) pada dasarnya merupakan data pengukuran yang diambil secara kronologis dalam kurun waktu tertentu (Lutkepol, 2005). Salah satu Model runtun waktu yang sering digunakan adalah ARIMA (Autoregressive Integrated Moving Average). Model runtun waktu ARIMA merupakan alat bantu dalam melakukan peramalan yang menggunakan teknik korelasi pada suatu deret waktu. Dasar pemikiran dari model ARIMA adalah pengamatan waktu sekarang tergantung pada satu atau beberapa pengamatan sebelumnya. Model ARIMA terdiri dari tiga proses yaitu autoregressive, integrated dan moving average dengan masing-masing memiliki order $(p, d, q)$. Pada prakteknya, perhitungan ARMA sering kali diperlakukan sebagai model ARIMA dengan tidak diperlukannya proses pembedaan (differencing) karena data sudah stasioner, sehingga model ARMA sering dituliskan sebagai model ARIMA $(p, 0, q)$ atau $\operatorname{ARMA}(p, q)$.

\section{Autoregressive (AR)}

Autoregressive adalah suatu bentuk regresi tetapi bukan yang menghubungkan variable tak bebas, melainkan menghubungkan nilai-nilai sebelumnya pada lag time (selang waktu) yang bermacam-macam. Jadi suatu model Autoregressive akan menyatakan suatu ramalan sebagai fungsi nilai-nilai sebelumnya dari time series terrtentu (Makridakis, 1999). Model Autoregressive (AR) dengan order $p$ dinotasikan dengan AR(p). Bentuk umum dari model runtun waktu untuk Autoregressive dinyatakan oleh :

$$
y_{t}=\phi_{1} y_{t-1}+\cdots+\phi_{p} y_{t-p}+\varepsilon_{t}
$$

dengan,

$y_{t} \quad=$ nilai variable pada waktu ke- $t, t=1,2, \ldots, n$,

$y_{t-1}, y_{t-2}, \ldots, y_{t-p}=$ nilai masa lalu dari time series yang bersangkutan pada waktu ke $t-1, t-2, . ., t-p$,

$\phi_{i} \quad=$ parameter AR tingkat $i, i=1,2,3, \ldots, p$,

$\varepsilon_{t} \quad=$ nilai error pada waktu ke-t,

$p \quad=$ order AR.

\section{Moving Average (MA)}

Metode ini dilakukan dengan mengambil sekelompok nilai pengamatan, mencari rata-ratanya kemudian menggunakan rata-rata tersebut sebagai ramalan untuk periode yang akan datang. Bentuk umum dari proses Moving Average order $q$ atau MA( $q$ ) didefinisikan sebagai berikut (Montgomery dkk, 2008) :

dengan,

$$
y_{t}=\theta_{0}+\varepsilon_{t}-\theta_{1} \varepsilon_{t-1}-\ldots-\theta_{q} \varepsilon_{t-q}
$$

$y_{t} \quad=$ nilai variabel pada waktu ke- $t, t=1,2, \ldots, n$,

$\theta_{0} \quad=$ suatu konstanta,

$\theta_{j} \quad=$ parameter MA tingkat $j, j=1,2, \ldots, q$,

$\varepsilon_{t-j} \quad=$ error pada periode $t-j, j=1,2, \ldots, q$,

$\varepsilon_{t} \quad=$ error pada periode $t$.

\section{Autoregressive Moving Average (ARMA)}

Model ARMA adalah gabungkan antara model autoregressive (AR) dan model moving average (MA). Metode ARMA ini juga sering disebut sebagai metoda Box-Jenkins karena dikembangkan oleh George Box dan Gwilym Jenkins pada tahun 1976 (Lutkepohl, 2005). Model ARMA dapat dituliskan sebagai berikut (Wei, 2006):

dengan ,

$\phi_{i} \quad=$ parameter AR tingkat $i, i=1,2,3, \ldots, p$,

$p \quad=$ order $\mathrm{AR}$,

$\theta_{i} \quad=$ parameter MA tingkat $i, i=1,2,3, \ldots, q$,

$q \quad=$ order MA.

Model ARMA dapat juga disederhanakan menggunakan operator backshift $(B)$ dengan penggunaan sebagai berikut :

$$
y_{t}=\phi_{1} y_{t-1}+\ldots+\phi_{p} y_{t-p}+\varepsilon_{t}-\theta_{1} \varepsilon_{t-1}-\ldots-\theta_{q} \varepsilon_{t-q}
$$

$$
B y_{t}=y_{t-1} \text {, }
$$

sehingga model ARMA dapat dinyatakan sebagai berikut :

$$
\phi_{p}(B) y_{t}=\theta_{q}(B) \varepsilon_{t} .
$$


Dalam penggunaannya menggunakan operator backshift, model ARMA musiman yaitu :

$$
\phi_{p}\left(B^{s}\right) y_{t}=\theta_{q}\left(B^{s}\right) \varepsilon_{t}
$$

dengan $\phi_{p}\left(B^{S}\right)$ menyatakan AR Musiman dan $\theta_{q}\left(B^{S}\right)$ menyatakan MA Musiman. Berikut ini adalah contoh penggunaan operator backshift pada model Autoregresivve (AR) musiman periode s tingkat $p$ atau $\operatorname{AR}(p)^{s}$ :

- Model AR 1 Musiman dengan periode 6 dapat dinyatakan sebagai

$$
\phi_{1}\left(B^{6}\right) y_{t}=\varepsilon_{t}
$$

dengan $\phi_{1}\left(B^{6}\right)=1-\phi B^{6}$ sehingga

$\left(1-\phi B^{6}\right) y_{t}=\varepsilon_{t}$,

$y_{t}-\phi B^{6} y_{t}=\varepsilon_{t}$,

$y_{t}-\phi y_{t-6}=\varepsilon_{t}$,

$y_{t}=\phi y_{t-6}+\varepsilon_{t}$.

- Model AR 2 Musiman dengan periode $s$ dapat dinyatakan sebagai

$$
\begin{aligned}
& \qquad \phi_{2}\left(B^{s}\right) y_{t}=\varepsilon_{t} \\
& \text { dengan } \phi_{2}\left(B^{s}\right)=1-\phi_{1} B^{s}-\phi_{2} B^{2 s} \text { sehingga } \\
& \left(1-\phi_{1} B^{s}-\phi_{2} B^{2 s}\right) y_{t}=\varepsilon_{t} \\
& y_{t}-\phi_{1} B^{s} y_{t}-\phi_{2} B^{2 s} y_{t}=\varepsilon_{t} \\
& y_{t}-\phi_{1} y_{t-s}-\phi_{2} y_{t-2 s}=\varepsilon_{t} \\
& y_{t}=\phi_{1} y_{t-s}+\phi_{2} y_{t-2 s}+\varepsilon_{t} .
\end{aligned}
$$

Selain itu, adapun contoh penggunaan operator backshift pada model Moving Average (MA) musiman periode $s$ tingkat $q$ atau $\mathrm{MA}(q)^{s}$ sebagai berikut :

- Model MA 1 Musiman dengan periode 12 dapat dinyatakan sebagai

$$
\begin{aligned}
& \quad y_{t}=\theta_{1}\left(B^{12}\right) \varepsilon_{t} \\
& \text { dengan } \theta_{1}\left(B^{12}\right)=1-\theta_{1} B^{12} \text { sehingga } \\
& y_{t}=\left(1-\theta_{1} B^{12}\right) \varepsilon_{t}, \\
& y_{t}=\varepsilon_{t}-\theta_{1} \varepsilon_{t-12} .
\end{aligned}
$$

- Model MA 2 Musiman dengan periode s dapat dinyatakan sebagai

$$
\begin{gathered}
y_{t}=\theta_{2}\left(B^{s}\right) \varepsilon_{t} \\
\text { dengan } \theta_{2}\left(B^{s}\right)=1-\theta_{1} B^{s}-\theta_{2} B^{2 s} \text { sehingga } \\
y_{t}=\left(1-\theta_{1} B^{s}-\theta_{2} B^{2 s}\right) \varepsilon_{t}, \\
y_{t}=\varepsilon_{t}-\theta_{1} \varepsilon_{t-s}-\theta_{2} \varepsilon_{t-2 s} .
\end{gathered}
$$

Sedangkan, bentuk umum AR 1 Musiman dengan intercept dapat dinyatakan sebagai berikut :

$$
y_{t}=\mu+\phi y_{t-s}+\varepsilon_{t} \text {. }
$$

Untuk periode tahunan dengan periode 12 , maka bentuk umumnya menjadi :

$$
y_{t}=\mu+\phi y_{t-12}+\varepsilon_{t} \text {. }
$$

dengan,

$y_{t} \quad=$ nilai variable pada waktu ke- $t$,

$\mu \quad=$ parameter intersept,

$\phi \quad=$ parameter AR,

$y_{t-12}=$ nilai masa lalu pada waktu ke $t-12$,

$\varepsilon_{t} \quad=$ error pada waktu ke-t.

Menurut Entin Hidayah dkk. (2011) dalam teori estimasi, salah satu pendekatan yang populer ialah pendekatan statistik Bayesian. Statistik Bayesian tidak hanya menggunakan data sampel dari populasi tetapi juga menggunakan distribusi prior untuk masing-masing parameter. Di sisi lain, pendekatan statistik Bayesian mengasumsikan bahwa parameter $\theta$ memiliki distribusi prior. Dengan menggabungkan informasi ini, sampel data digunakan untuk menghitung Likelihood dan distribusi Prior dari parameter, sehingga distribusi posterior untuk setiap parameter bisa ditentukan. Kemudian, estimasi parameter dapat diturunkan dari posterior tersebut. Teori Bayesian mencakup cara untuk memprediksi parameter menggunakan distribusi posterior secara langsung. Dengan mengkombinasikan dengan model runtun waktu ARIMA, maka salah satu bentuk umum dari Bayesian AR 1 Musiman dengan periode 12 ialah sebagai berikut :

$$
y_{t}=X_{i}^{T} \beta+\varepsilon_{i}
$$


dengan,

$$
\left[\begin{array}{c}
y_{t} \\
\vdots \\
y_{n}
\end{array}\right]=\left[\begin{array}{cc}
1 & y_{t-12} \\
\vdots & \vdots \\
1 & y_{n-12}
\end{array}\right]\left[\begin{array}{c}
\mu \\
\phi
\end{array}\right]+\left[\begin{array}{c}
\varepsilon_{t} \\
\vdots \\
\varepsilon_{n}
\end{array}\right]
$$

$y_{t} \quad=$ vektor kolom untuk pengamatan ke- $t, t=13, \ldots, n$,

$X_{i}^{T} \quad=$ matrik berdimensi $n \times k$, karena hanya 1 variabel menjadi $\left[\begin{array}{cc}1 & y_{t-12} \\ \vdots & \vdots \\ 1 & y_{n-12}\end{array}\right]$,

$\beta=$ vektor kolom dari yang berisi nilai $\mu$ dan $\phi$,

$\varepsilon_{t} \quad=$ besarnya error ke- $t, t=13, \ldots, n$,

$n \quad$ = banyaknya data asli.

Menurut Mutiarani dkk. (2012) fungsi likelihood yang tepat yaitu :

$$
p\left(y \mid X, \beta, \sigma^{2}\right) \propto\left(\sigma^{2}\right)^{-\frac{n}{2}} \exp \left(-\frac{1}{2 \sigma^{2}}(y-X \beta)^{T}(y-X \beta)\right) .
$$

Dengan metode Least Square diperoleh estimasi dari $\beta$ yaitu :

$$
\hat{\beta}=\left(X^{T} X\right)^{-1} X^{T} y \text {. }
$$

Parameter variansi $\sigma^{2}$ dapat di estimasi dengan Sisaan Kuadrat Rata-rata (SKR) sebagai berikut (Setiawan, 2017):

$$
\widehat{\sigma^{2}}=\frac{J K S}{n-2}
$$

\section{Distribusi Prior Konjugat}

Prior konjugat adalah suatu prior yang jika dikombinasikan dengan fungsi likelihood akan menghasilkan suatu posterior dengan distribusi yang sama dengan distribusi prior (Gelman, 2006).

Bentuk untuk prior sebagai berikut :

$$
p\left(\beta, \sigma^{2}\right)=p\left(\sigma^{2}\right) p\left(\beta \mid \sigma^{2}\right) .
$$

Dalam hal ini distribusi Invers Gamma (IG) dapat dinyatakan dengan persamaan sebagai berikut :

$$
f(x)=\frac{b^{a}}{\Gamma(a)} x^{-(a+1)} \exp \left(-\frac{b}{x}\right) \quad a>0, b>0, x>0
$$

Pada distribusi Invers Gamma tersebut, notasi $a$ menyatakan shape dan $b$ menyatakan rate atau dapat juga dinyatakan dengan $I G\left(a_{0}, b_{0}\right)$ dengan $a_{0}=\frac{v_{0}}{2}$ dan $b_{0}=\frac{1}{2} v_{0} s_{0}^{2}$ dengan $v_{0}$ dan $s_{0}^{2}$ diperoleh dari informasi awal atau ditentukan secara bebas (subyektif). Kepadatan prior ditulis sebagai :

$$
p\left(\sigma^{2}\right) \propto\left(\sigma^{2}\right)^{-\frac{v_{0}}{2}-1} \exp \left(-\frac{v_{0} s_{0}^{2}}{2 \sigma^{2}}\right) .
$$

Selain itu, distribusi Normal $(N)$ dapat dinyatakan dengan persamaan sebagai berikut :

$$
\frac{1}{\sqrt{2 \pi \sigma^{2}}} e^{\frac{-(X-\mu)^{2}}{2 \sigma^{2}}}
$$

Lebih lanjut, prior bersyarat $\beta \mid \sigma^{2}$ berdistribusi normal yang dinotasikan sebagai $N\left(\mu_{0}, \sigma^{2} \Lambda_{0}^{-1}\right)$ dengan $\mu_{0}$ yang dapat dipilih secara bebas (subjektif) dan memiliki kepadatan prior bersyarat :

$$
p\left(\beta \mid \sigma^{2}\right) \propto\left(\sigma^{2}\right)^{-\frac{k}{2}} \exp \left(-\frac{1}{2 \sigma^{2}}\left(\beta-\mu_{0}\right)^{T} \Lambda_{0}\left(\beta-\mu_{0}\right)\right) .
$$

\section{Distribusi Posterior} berikut:

Untuk menyatakan distribusi posterior, digunakan teorema Bayes yaitu dapat dinyatakan sebagai

$$
\text { Posterior } \propto \text { Likelihood } \times \text { Prior }
$$


Tanda $\propto$ menyatakan "sebanding dengan" sehingga mempunyai arti jika posterior sebanding dengan likelihood pada persamaan (8) dikalikan prior yang telah ditentukan pada persamaan (11), distribusi posterior dapat dinyatakan sebagai

$$
\begin{aligned}
p\left(\beta, \sigma^{2} \mid y, X\right) & \propto p\left(y \mid X, \beta, \sigma^{2}\right) p\left(\beta \mid \sigma^{2}\right) p\left(\sigma^{2}\right) \\
\propto & \left(\sigma^{2}\right)^{-\frac{n}{2}} \exp \left(-\frac{1}{2 \sigma^{2}}(y-X \beta)^{T}(y-X \beta)\right)\left(\sigma^{2}\right)^{-\frac{k}{2}} \quad x \\
& \quad \exp \left(-\frac{1}{2 \sigma^{2}}\left(\beta-\mu_{0}\right)^{T} \Lambda_{0}\left(\beta-\mu_{0}\right)\right)\left(\sigma^{2}\right)^{-\left(a_{0}+1\right)} \exp \left(-\frac{b_{0}}{\sigma^{2}}\right) .
\end{aligned}
$$

Selanjutnya, posterior dapat juga dinyatakan sebagai distribusi normal dikalikan dengan distribusi invers-gamma :

$$
\begin{aligned}
& p\left(\beta, \sigma^{2} \mid y, X\right) \propto\left(\sigma^{2}\right)^{-\frac{k}{2}} \exp \left(-\frac{1}{2 \sigma^{2}}\left(\beta-\mu_{n}\right)^{T}\left(X^{T} X+\Lambda_{0}\right)\left(\beta-\mu_{n}\right)\right) x \\
&\left(\sigma^{2}\right)^{-\frac{n+v_{0}}{2}-1} \exp \left(\frac{2 b_{0}+y^{T} y-\mu_{n}^{T}\left(X^{T} X+\Lambda_{0}\right) \mu_{n}+\mu_{0}^{T} \Lambda_{0} \mu_{0}}{2 \sigma^{2}}\right) .
\end{aligned}
$$

Oleh karena itu, distribusi posterior dapat di parameterisasi sebagai berikut :

$$
p\left(\beta, \sigma^{2} \mid y, X\right) \propto p\left(\beta \mid \sigma^{2}, y, X\right) p\left(\sigma^{2} \mid y, X\right) .
$$

dengan kedua faktor sesuai dengan kepadatan dari distribusi $N\left(\mu_{n}, \sigma^{2} \Lambda_{n}^{-1}\right)$ dan distribusi $/ G\left(a_{n}, b_{n}\right)$ dengan parameternya diberikan oleh,

$$
\begin{array}{ll}
\Lambda_{n} & =\left(X^{T} X+\Lambda_{0}\right), \\
a_{n} & =a_{0}+\frac{n}{2} \\
b_{n} & =b_{0}+\frac{1}{2}\left(y^{T} y+\mu_{0}^{T} \Lambda_{0} \mu_{0}-\mu_{n}^{T} \Lambda_{\mathrm{n}} \mu_{n}\right) \\
\mu_{n} & =\left(\Lambda_{n}\right)^{-1}\left(X^{T} X \hat{\beta}+\Lambda_{0} \mu_{0}\right) .
\end{array}
$$

\section{METODE PENELITIAN}

Data yang digunakan dalam penelitian ini merupakan data sekunder dari bulan Januari 2013 sampai dengan Mei 2018 untuk semua jenis mobil.

Langkah-langkah dalam pengolahan data menurut Coghlan (2017) sebagai berikut :

\section{Menguji kestasioneran data.}

Suatu data dikatakan stasioner apabila tidak adanya perubahan drastis pada data. Fluktuasi yang terjadi pada data berada pada sekitaran nilai-nilai yang konstan, tidak bergantung pada waktu dan variansi dari fluktuasi tersebut (Makridakis, 1999). Stasioner sangat dibutuhkan sebagai syarat sebelum menentukan model menggunakan analisis runtun waktu. Uji stasioner dengan Augmented Dickey Fuller (ADF) Test merupakan pengujian stasioner dengan menentukan apakah data runtun waktu mengandung akar unit (unit root). Jika suatu data runtun waktu tidak stasioner maka stasioneritas data dapat dicari dengan melakukan differensial hingga diperoleh data yang stasioner. Dalam paket program $\mathrm{R}$ dapat digunakan fungsi "adf.test".

2. Membuat grafik ACF dan PACF untuk menganalisis model apa yang digunakan.

Penentuan model dari data runtun waktu dapat dilakukan dengan melihat grafik ACF (Auto Correlation Function) dan PACF (Partial Auto Correlation Function). Pada ACF menghitung korelasi antara nilai $t$ dengan nilai $t+k$ namun masih memperhitungkan nilai-nilai yang ada diantaranya secara keseluruhan data, sedangkan pada PACF menghitung korelasi secara parsial pada nilai yang sama tanpa dipengaruhi nilai-nilai diantaranya.

3. Menguji normalitas residual dengan menggunakan uji Kolmogorov-Smirnov dan uji Shapiro Test.

Menurut Setiawan (2017), uji Kolmogorov-Smirnov dapat digunakan untuk menguji normalitas dari data. Begitu pula dengan uji Shapiro Test yang juga merupakan uji normalitas yang efektif dan valid digunakan untuk sampel berjumlah kecil. Dalam paket program R dapat digunakan fungsi "ks.test" dan "shapiro.test". 
4. Menghitung nilai $\widehat{\boldsymbol{\beta}}$ dan $\sigma^{2}$ menggunakan metode Least Square.

Perhitungan ini digunakan untuk mendapatkan nilai estimasi parameter dari $\mu, \phi$ dan $\sigma^{2}$ menggunakan rumus Least Square pada persamaan (9) dan (10).

5. Mengestimasi parameter model menggunakan metode Bayesian AR 1 Musiman.

Perhitungan ini digunakan untuk mendapatkan nilai estimasi parameter dari $\mu, \phi$ dan $\sigma^{2}$ menggunakan rumus pada persamaan (18), namun pada prakteknya digunakan algoritma untuk membangkitkan data hingga 10.000 kali yang terdapat pada persamaan (19), (20), (21) dan (22).

Berikut ialah Algoritma untuk membangkitkan $\beta$ dan $\sigma^{2}$ dengan $\beta=\mu, \phi$.

1. Bangkitkan $\sigma^{2} \sim I G\left(\right.$ shape $=a_{n}$, rate $\left.=b_{n}\right)$ dengan,

$a_{n}: a_{0}+\frac{n}{2}$, dengan $a_{0}=\frac{v_{0}}{2}$

$b_{n} \quad: b_{0}+\frac{1}{2}\left(y^{T} y+\mu_{0}^{T} \Lambda_{0} \mu_{0}-\mu_{n}^{T} \Lambda_{\mathrm{n}} \mu_{n}\right)$, dengan $b_{0}=\frac{v_{0} s_{0}^{2}}{2}$

nilai $v_{0}$ dan $s_{0}^{2}$ dipilih secara subjektif

$\mu_{0} \quad: \hat{\beta}$, dengan $\left(X^{T} X\right)^{-1} X^{T} y$

$\Lambda_{0} \quad$ : Matriks identitas $2 \times 2$.

2. Bangkitkan $\beta \sim N_{2}\left(\mu_{n}, \sigma^{2} \Lambda_{n}^{-1}\right)$ dengan,

$\sigma^{2} \quad$ : hasil pembangkitan pada langkah 1 .

$\Lambda_{n}^{-1} \quad:\left(X^{T} X+\Lambda_{0}\right)^{-1}$

$\mu_{n}:\left(\Lambda_{n}\right)^{-1}\left(X^{T} X \hat{\beta}+\Lambda_{0} \mu_{0}\right)$.

Prosedur diulang hingga $M=10.000$, sehingga diperoleh $\left(\beta_{1}, \sigma^{2}{ }_{1}\right),\left(\beta_{2}, \sigma^{2}{ }_{2}\right), \ldots,\left(\beta_{10000}, \sigma^{2}{ }_{10000}\right)$. Selanjutnya untuk mendapatkan nilai parameternya, dapat dicari menggunakan nilai rata-rata (mean) dari 10.000 data yang telah dibangkitkan.

\section{HASIL DAN DISKUSI}

\section{Menguji kestasioneran data.}

Setelah data diperoleh, dilakukan uji stasioneritas untuk mengetahui kestasioneran data menggunakan uji adf.test (Augmented Dickey Fuller Test) untuk mengetahui nilai- $p$ nya. Jika nilai- $p<0.05$ artinya data sudah stasioner, namun jika nilai- $p>0.05$ artinya data belum stasioner dan perlu differensialkan hingga diperoleh data yang stasioner. Berdasarkan perhitungan menggunakan program $\mathrm{R}$ pada Gambar 1 diperoleh nilai-p sebesar 0.0324 yang artinya data penjualan tersebut sudah stasioner. Selanjutnya, Gambar 2 menunjukkan grafik penjualan mobil setiap bulannya dari bulan Januari 2013 sampai dengan Mei 2018. Terlihat bahwa grafik penjualan fluktuatif namun telah stasioner.

Augmented Dickey-Fuller Test

data: a

Dickey-Fuller $=-3.6933$, Lag order $=3$, p-value $=0.0324$

alternative hypothesis: stationary

Gambar 1. Hasil Uji Adf Test

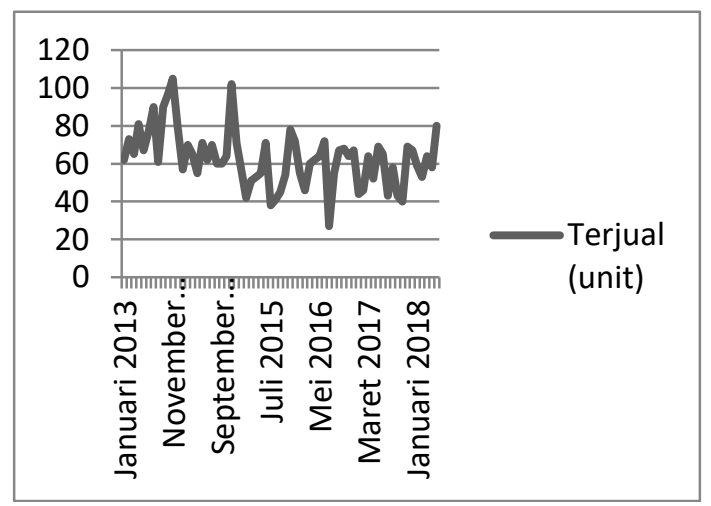

Gambar 2. Grafik Penjualan Januari 2013-Mei 2018 


\section{Membuat grafik ACF dan PACF untuk menganalisis model apa yang digunakan.}

Setelah didapatkan data yang stasioner, langkah selanjutnya ialah membuat grafik ACF dan PACF untuk menganalisis model apa yang digunakan seperti yang ditunjukkan pada Gambar 3, gambar bagian atas menunjukkan grafik ACF dan gambar bagian bawah menunjukkan grafik PACF. Dari analisis grafik ACF didapatkan bahwa grafik cenderung menurun pada lag kelipatan 12 dan pada grafik PACF cenderung signifikan hanya pada lag 12 sehingga dipilih model AR 1 (Autoregressive). Karena pada lag ke 12 data signifikan maka artinya data tersebut musiman. Akibatnya data tersebut mempunyai model AR 1 Musiman.

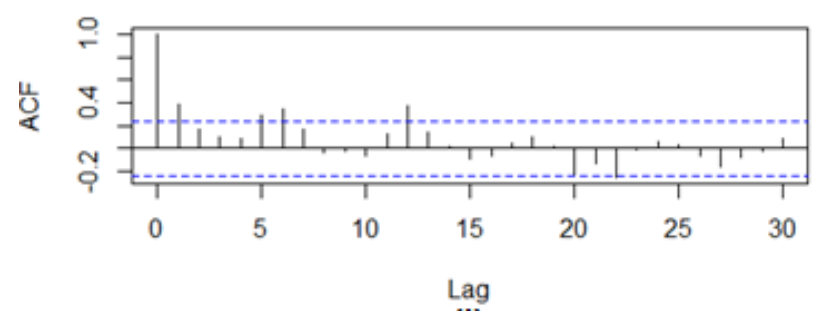

(i)

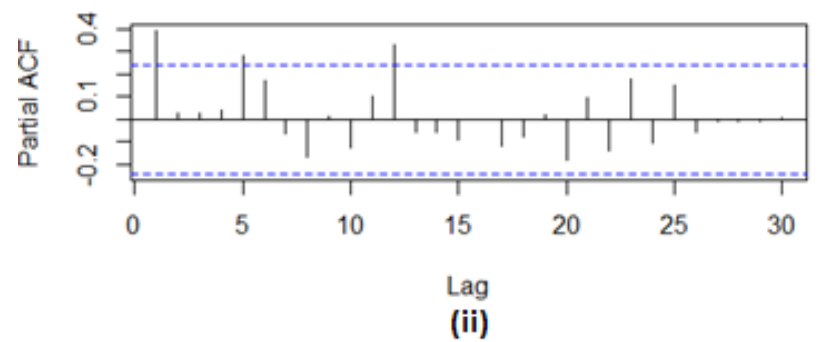

Gambar 3. Grafik ACF (i) dan PACF (ii)

3. Menguji normalitas residual dengan menggunakan uji Kolmogorov-Smirnov dan uji Shapiro Test.

Setelah mendapatkan model runtun waktu yang tepat yaitu AR 1 Musiman, dilakukan uji normalitas residual untuk mengetahui kenormalan data. Gambar 4 menunjukkan bahwa titik-titik mendekati garis lurus yang artinya residu cenderung normal.

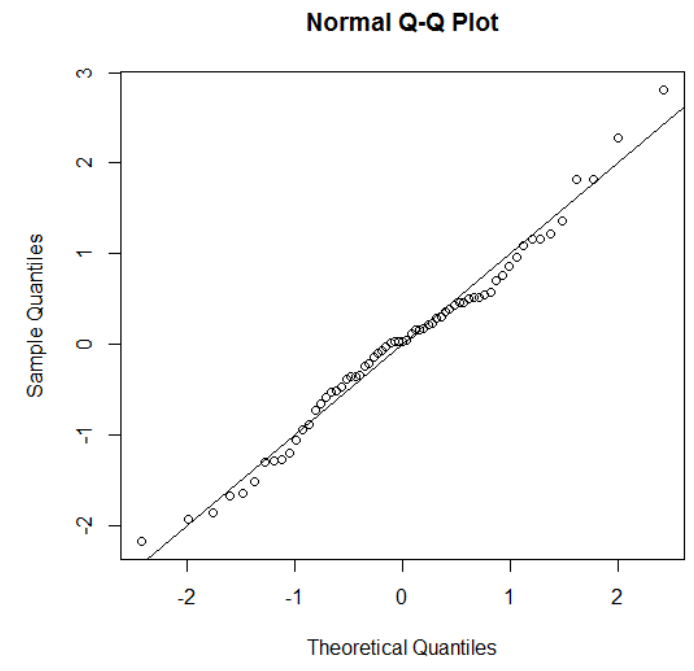

Gambar 4. Plot Q-Q Norm

Selanjutnya, dilakukan uji normalitas residual dengan menggunakan uji Kolmogorov-Smirnov dan uji Shapiro Test. Jika didapatkan nilai- $p \geq 0.05$ artinya residu normal, namun jika didapatkan nilai- $p<0.05$ artinya residu tidak normal. Pada Gambar 5 menunjukkan bahwa hasil dari uji Kolmogorov-Smirnov didapatkan nilai- $p$ sebesar 0.7771 yang artinya residu tersebut normal. Serta pada Gambar 6 menunjukkan bahwa hasil dari uji Shapiro Test didapatkan nilai- $p$ sebesar 0.5441 yang artinya data tersebut juga normal. 


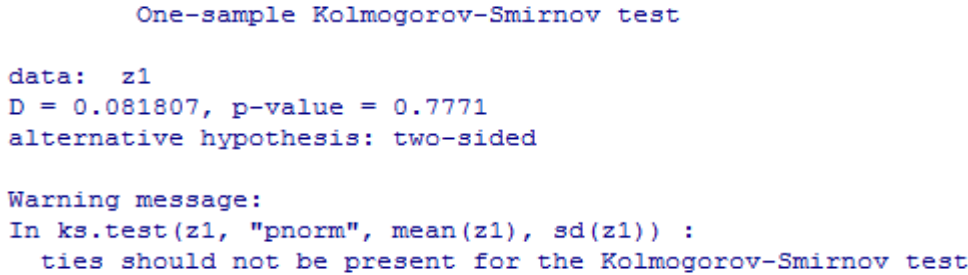

Gambar 5. Hasil Uji Kolmogorov - Smirnov

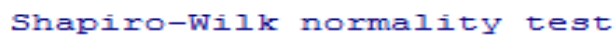

Gambar 6. Hasil Uji Shapiro-Test

\section{Menghitung nilai $\widehat{\beta}$ dan $\sigma^{2}$ menggunakan metode Least Square.}

Setelah mengetahui bahwa model data adalah AR 1 Musiman dengan periode 12, dilakukan perhitungan menggunakan metode Least Square pada persamaan (9) dan (10). Tabel 1 menunjukkan hasil perhitungan menggunakan metode tersebut.

Tabel 1. Hasil Perhitungan Menggunakan Metode Least Square

\begin{tabular}{|c|c|}
\hline$\mu$ & 30.8831 \\
\hline$\phi$ & 0.4443 \\
\hline$\sigma^{2}$ & 115.4799 \\
\hline
\end{tabular}

\section{Mengestimasi parameter model menggunakan metode Bayesian AR 1 Musiman.}

Langkah selanjutnya yaitu mengestimasi parameter $\mu, \phi$, dan $\sigma^{2}$ menggunakan rumus pada persamaan (18) yang pada prakteknya menggunakan bantuan algoritma. Perhitungan dilakukan dengan membangkitkan data sebanyak 10.000 kali. Gambar 7 (i) menunjukkan plot Bayesian MCMC (Marcov Chain Monte Carlo) dan plot densitas dari $\mu$ yang berkisar di angka 30, Gambar 7 (ii) menunjukkan plot Bayesian MCMC dan plot densitas dari $\phi$ yang berkisar di angka 0.4 dan Gambar 7 (iii) menunjukkan plot Bayesian MCMC dan plot densitas dari $\sigma^{2}$ yang berkisar di angka 100. Untuk perhitungan lebih tepatnya, nilai parameter $\mu, \phi$ dan $\sigma^{2}$ yang telah dihitung menggunakan metode Bayesian dinyatakan dalam Tabel 2.

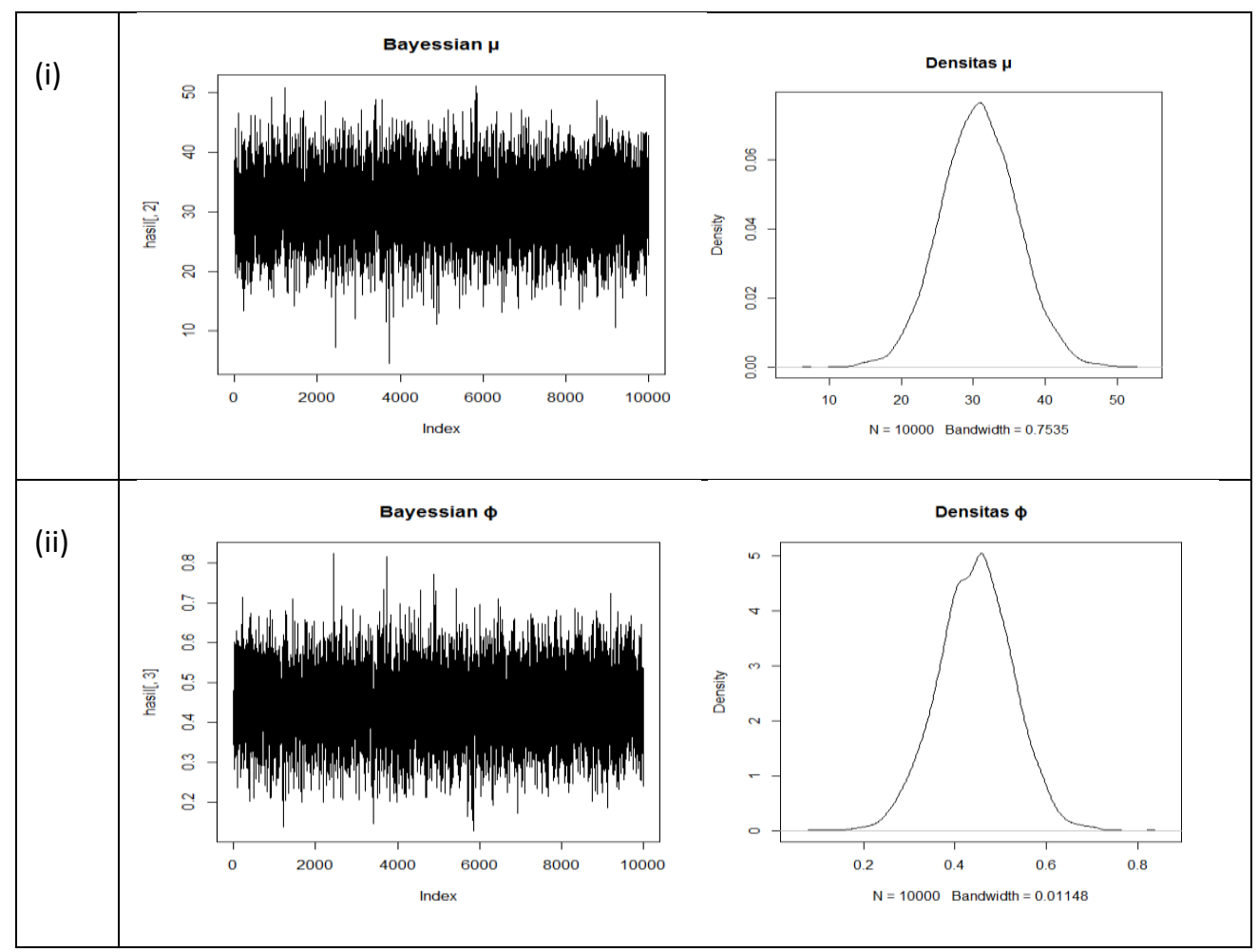




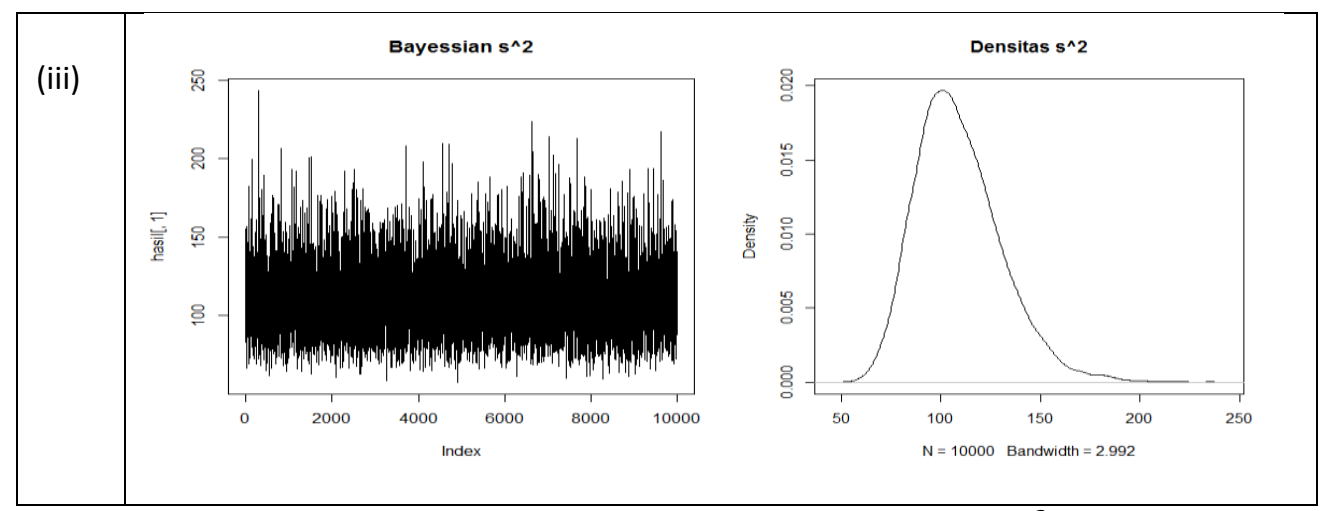

Gambar 7. Plot Densitas dan Plot Bayesian $\mu, \phi, \sigma^{2}$

Tabel 2. Nilai Mean dan Median dari $\mu, \phi$, dan $\sigma^{2}$

\begin{tabular}{|c|c|c|c|}
\hline & Mean & Median & Interval Kepercayaan 95\% \\
\hline$\mu$ & 30.9238 & 30.8028 & {$[22.3994,39.4436]$} \\
\hline$\phi$ & 0.4439 & 0.4452 & {$[0.3139,0.5756]$} \\
\hline$\sigma^{2}$ & 109.0879 & 106.4848 & {$[75.4906,158.4349]$} \\
\hline
\end{tabular}

Dari hasil perhitungan di atas, kolom mean merupakan hasil estimasi parameter dari $\mu, \phi$, dan $\sigma^{2}$ menggunakan metode Bayesian AR 1 dengan Intercept. Hal ini menunjukkan bahwa hasil perhitungan menggunakan metode Bayesian mendekati hasil perhitungan menggunakan metode Least Square sehingga didapatkan model penjualan mobil yang telah dianalisis menggunakan metode Bayesian dengan Model Autoregressive 1 Musiman sebagai berikut :

$$
\begin{gathered}
y_{t}=\mu+\phi y_{t-12}+\varepsilon_{t} \\
y_{t}=30.9238+0.4439 y_{t-12}+\varepsilon_{t} .
\end{gathered}
$$

Penelitian ini masih menggunakan metode Bayesian sederhana, berbeda dengan penelitian yang dilakukan oleh Suparman and Doisy (2014) yang menggunakan Bayesian Hierarki. Metode yang digunakan juga berbeda, pada kasus ini menggunakan Bayesian MCMC Gibbs sampling, jika Suparman and Doisy (2014) menggunakan MCMC Simulated Anneling Algoritm. Sedangkan pada penelitian yang dilakukan oleh Entin Hidayah dkk. (2011) hampir memiliki kesamaan yaitu penggunaan Bayesian AR 1 Musiman, hanya saja metode tersebut digunakan pada struktur model hujan.

\section{KESIMPULAN}

Berdasarkan hasil perhitungan dan pembahasan didapatkan bahwa untuk mengestimasi parameter dalam model AR 1 Musiman bisa digunakan metode Bayesian. Setelah dilakukan analisis menggunakan model Autoregressive Moving Average berdasarkan metode Bayesian didapatkan model penjualan yaitu: $y_{t}=30.9238+0.4439 y_{t-12}+\varepsilon_{t}$.

\section{DAFTAR PUSTAKA}

Coghlan, A. (2017). A Little Book of R For Time Series Release 02. Cambridge: Parasite Genomics Group, Wellcome Trust Sanger Institute.

Gelman, Andrew. (2006). Bayesian Analysis. Department of Statistics and Department of Political Science: Columbia University.

Hidayah, E., Iriawan, N., Anwar, N., \& Edijatno. (2011). Generating Hourly Rainfall Model using Bayesian Time Series Model (A Case Study at Sentral Station, Bondowoso). The Journal for Technology and Science, 22(1), 50-56.

Lutkepohl, Helmut. (2005). New Introduction to Multiple Time Series Analysis. Berlin: Springer

Makridakis, S., Wright, S.C.W., \& Mc Gee V. (1999). Metode dan Aplikasi Peramalan Jilid 1. Terjemahan Hari Suminto. Jakarta: Binarupa Aksara. 
Montgomery, D. C., Jennings, C. L., \& Kulahci, M. (2008). Introduction to Time Series Analysis and Forecasting. Canada: Wiley Interscience.

Mutiarani, V., Setiawan, A., \& Parhusip, H. A. (2012). Penerapan Model Regresi Linier Bayesian untuk Mengestimasi Parameter dan Interval Kredibel. In Seminar Nasional Matematika dan Pendidikan Matematika (pp. 54-57). Yogyakarta: Seminar Nasional Matematika dan Pendidikan Matematika FMIPA UNY.

Setiawan, A. (2017). Analisis Data Statistik. Salatiga: Tisara Grafika.

Suparman, and Doisy, M. (2014). Hierarchical Bayesian of ARMA Models Using Simulated Annealing Algorithm. Telkomnika, 12(1), 87-96. https://doi.org/10.12928/TELKOMNIKA.v12i1.1706

Wei, W. (2006). Time Series Analysis Univariate and Multivariate Methods Second Edition. New York: Pearson Education. 